\title{
Sourcing and Propagation of Pontechium maculatum for Horticulture and Species Restoration
}

\author{
Barbara Nowak*(1), Ewa Sitek $(\mathbb{1}$ and Joanna Augustynowicz \\ Department of Botany, Physiology and Plant Protection, Faculty of Biotechnology and Horticulture, \\ University of Agriculture in Krakow, al. 29 Listopada 54, 31-425 Krakow, Poland; ewa.sitek@urk.edu.pl (E.S.); \\ j.augustynowicz@urk.edu.pl (J.A.) \\ * Correspondence: barbara.nowak@urk.edu.pl; Tel.: +48-12-662-525198; Fax: +48-12-662-5266
}

Received: 7 August 2020; Accepted: 28 September 2020; Published: 30 September 2020

Simple Summary: Russian bugloss, a species of ornamental, apicultural and medicinal value, is threatened in some Central European countries. To restrict its overexploitation from nature the alternative method of propagation using tissue culture was elaborated here. Additionally, the generative reproductive ability was compared for two groups of plants obtained from seeds (received from Germany and representing the Polish vanishing population) and those of in vitro origin. It was proved that the German seed-origin plants had the greatest propagation efficacy and developed the greatest number of seeds. The ability of seeds to germinate was similar for all plants; however, seeds were in a state of dormancy, which can be broken using plant growth regulators. It was also proved that cultivation in vitro can induce some variability among received plants, which makes this way of Russian bugloss propagation a potential breeding tool.

\begin{abstract}
Pontechium maculatum, a species of ornamental, apicultural, health and medicinal value, is threatened in some Central European countries including Poland. Its propagation using seeds or in vitro techniques is needed for multiple applications including conservation. Generative propagation efficacy of P. maculatum plants representing different genetic resources (received from botanical gardens in Germany and in Poland) propagated from seeds or in tissue culture was assessed. Moreover, an efficient technique of propagation of $P$. maculatum using in vitro shoot culture from seedlings was elaborated for the first time. The highest propagation efficacy was noted for German plants of seed origin. The ability of seeds to germinate was similar for all plants; however, seeds were in a state of dormancy, which was broken by $\mathrm{GA}_{3}$. After two years of storage, the seeds still retained the ability to germinate though seeds from propagated in vitro plants germinated more poorly than those from seed-originated plants. The ploidy assessment showed that some in vitro-origin plants had altered DNA content. The results indicate that efficacy of generative propagation of $P$. maculatum is resource dependent. Furthermore, results suggest that cultivation in vitro influenced some generative features of examined species, which makes this way of $P$. maculatum propagation a valuable source of genetic variation and a potential breeding tool.
\end{abstract}

Keywords: Echium russicum; generative propagation; in vitro; medicinal plants; Pontechium maculatum; Russian bugloss; seed dormancy; species rehabilitation

\section{Introduction}

Natural resources of cultivated plant species are declining mostly because of their excessive exploitation. As a result, a lot of useful species and crop relatives have disappeared in the wild or their populations are endangered [1]. An alternative plant source for both applied purposes and species conservation are of great need. However, the choice of the propagule source and the method of 
propagation is a challenge. In the case of rare species, particularly of limited reproductive abilities or declining populations, efficient methods of propagation are of great value. In horticulture, the priority are the methods allowing to obtain great number of plants, possibly uniform, and in a relatively short period of time. The micropropagation cloning technique is such a method [2].

In turn, in case of efforts aimed at restoration of plant populations, the first concern is to ensure the greatest possible genetic variability, from which arises serious dilemmas. A crucial one is the origin of propagules. It is commonly accepted that the greatest benefit comes from using seeds from the mother population. Such strategy allows keeping an existing and often unique gene pool [3]. Using local material guarantees keeping beneficial traits of local ecotype, best suited for local conditions. On the other hand such, declining, especially isolated, populations are characterized by poor gene pool due to genetic erosion and inbreeding depression, which limits their reproduction and adaptation abilities [4]. Strategy of mixed seed sources can support, in such situations, successful species rehabilitation in the wild, and preserve them also as a gene source for the future $[5,6]$.

Russian bugloss (Pontechium maculatum (L.) U.-R. Böhle and H.H. Hilger) was previously known as Echium russicum J.F.Gmel with chromosome number $2 n=24$, which is treated as diploid, triploid or tetraploid $[7,8]$. Divergances in the assessment of plant ploidy indicate how knowledge about this species is limited, additionally emphasizing the need to learn about its propagation biology. It is a biennial or perennial plant from the Boraginaceae family. Classified as hemicryptohyte, in the first year it forms a rosette of lanceolate leaves. In the second year it develops an inflorescence which is $10-40 \mathrm{~cm}$ long and consists of numerous helikoid cymeses. The flowering period typically lasts 2-3 weeks and falls in either May or June. The fruit is a schizocarp that splits into four one-seeded mericarps. In the successive vegetation seasons at the base of the parental rosette, some daughter rosettes emerge, which can be used for vegetative propagation [9].

Because of a considerable amount of nectar being produced, Russian bugloss is a plant of great apicultural value. The nectar is secreted by four nectary glands located at the base of the ovary [10]. As other plants from Boraginaceae family, Russian bugloss contains valuable compounds which make it a natural source of antioxidants [11]. It contains a considerable amount of rosmarinic acid and shikonine-well-known compounds with medicinal properties [12,13]. The seeds with high content of omega-3 and omega- 6 fatty acids make it a valuable plant for cultivation and production of useful fatty acids [14]. It has been used as an anti-inflammatory medicine that accelerates wound healing and is applied against snakebites [15].

The ornamental value of this plant, resulting from its beautiful and original inflorescences, makes it a valuable horticultural plant known as Redflowered viper's bugloss. It is recommended by the producers in Europe and the USA as a species suitable for dry, sunlit places [16].

The Russian bugloss is a Pontic-Pannonian sub-element, which spans over Central and Eastern Europe, the Caucasus and Anatolia [17]. It occurs in many European countries, but in some regions it is an endangered species $[9,16,18,19]$. It is also included in Annexes II and IV of the Habitat Directive 92/43/EU (as amended by the Directive 2013/17/EU) which covers European species requiring strict protection and special areas of conservation.

The north-western geographical range limit of P. maculatum crosses through Poland [17]. The Polish range of the species is located within the Lublin Upland and the Volhynian Upland. Monitoring conducted in 2013 revealed only three localities out of all known historical ones and the presence of only seven wild growing specimens. P. maculatum in Poland is a critically endangered (CR) species under legal protection requiring active conservation [9].

To conserve and to propagate wild crop relatives, some key information is needed, particulary that related to reproductive biology, reproductive output and variability among populations [20-22], which have not been investigated for Pontechium maculatum yet. Another approach to propagation and conservation are micropropagation techniques. The plants derived from tissue culture can be used in horticulture, the medicinal/pharmaceutical industry and as living plant collections in botanical gardens instead of plants collected from wild populations [23]. 
In Boraginaceae plants, tissue cultures are mainly used as a source for the production of valuable secondary metabolites. Numerous papers have described cultivation of callus and suspension, from which compounds were obtained for industrial purposes [24,25]. Secondary metabolites of medicinal properties were obtained from cotyledon-originated callus of Echium amoenum Fisch. and C.A. Mey., species from the Iran area [26]. Callus induced on explants excised from seedlings was a good source of shikonin [27], whereas regeneration of adventitious buds was described only for two endemic species, E. amoenum and E. orientale L. [28,29], where the differentiation took the form of indirect organogenesis which involved the callus phase.

Propagation of plants in tissue culture is associated with the risk of emergence of somaclonal variation resulting from conditions of cultivation. Probability of such variation is difficult to estimate and it depends on many factors, such as the type of initial explants and ways of regeneration [30]. The least variation is expected in cultures initiated from seeds sown on a medium, from which shoot cultures are derived with omission of the callus. Such a way of in vitro propagation for Pontechium and Echium genus has not been described yet.

The aim of the current work was (1) description of biology of generative propagation of P. maculatum, with particular emphasis on seed production and their ability to germinate at the moment of harvest and after storage, for three groups of plants of different origin including in vitro-origin ones, and (2) to elaborate on an effective method of propagation from seeds using in vitro shoot culture. Two hypotheses were verified. (1) The ability for generative propagation of $P$. maculatum representing a Polish declining population differ from such abilities of the other resources of this species. (2) Propagation in vitro does not cause substantial changes limiting generative propagation.

\section{Materials and Methods}

\subsection{Plant Material}

In this study, plants obtained from seeds received from the Botanical Garden of Maria Curie-Sklodowska University in Lublin and plants from seeds received from Germany Universität Bayreuth Ökolog-Botanischer Garten were used. Seeds from Germany were used as a source material for shoot cultures in vitro. Seeds from Polish botanical garden represent Polish natural resources from no longer existing populations in Czumów (further in the manuscript described as Polish origin). Seeds obtained from German botanical garden were of unknown origin (described as German origin).

\subsection{Ex Vitro Plants from Seeds}

Seeds of both origins were sown on 2 January 2012 into boxes $(25 \times 35 \times 8 \mathrm{~cm})$ with peat substrate and sand mixture in ratio 3:1 (Figure 1a). The germination was carried out for four weeks in Sanyo vegetative chambers, under $16 / 8 \mathrm{~h}$ day/night photoperiod and photon flux density of $60 \mu \mathrm{mol} \mathrm{m} \mathrm{m} \mathrm{s}^{-1}$, at $24 / 20{ }^{\circ} \mathrm{C}$, with humidity $60 \%$. One month later, the plants were replanted in pots and were cultivated in open field conditions in the collection of the Department of Botany, Physiology and Plant Protection of the University of Agriculture in Krakow (Kraków Poland) for one season. 


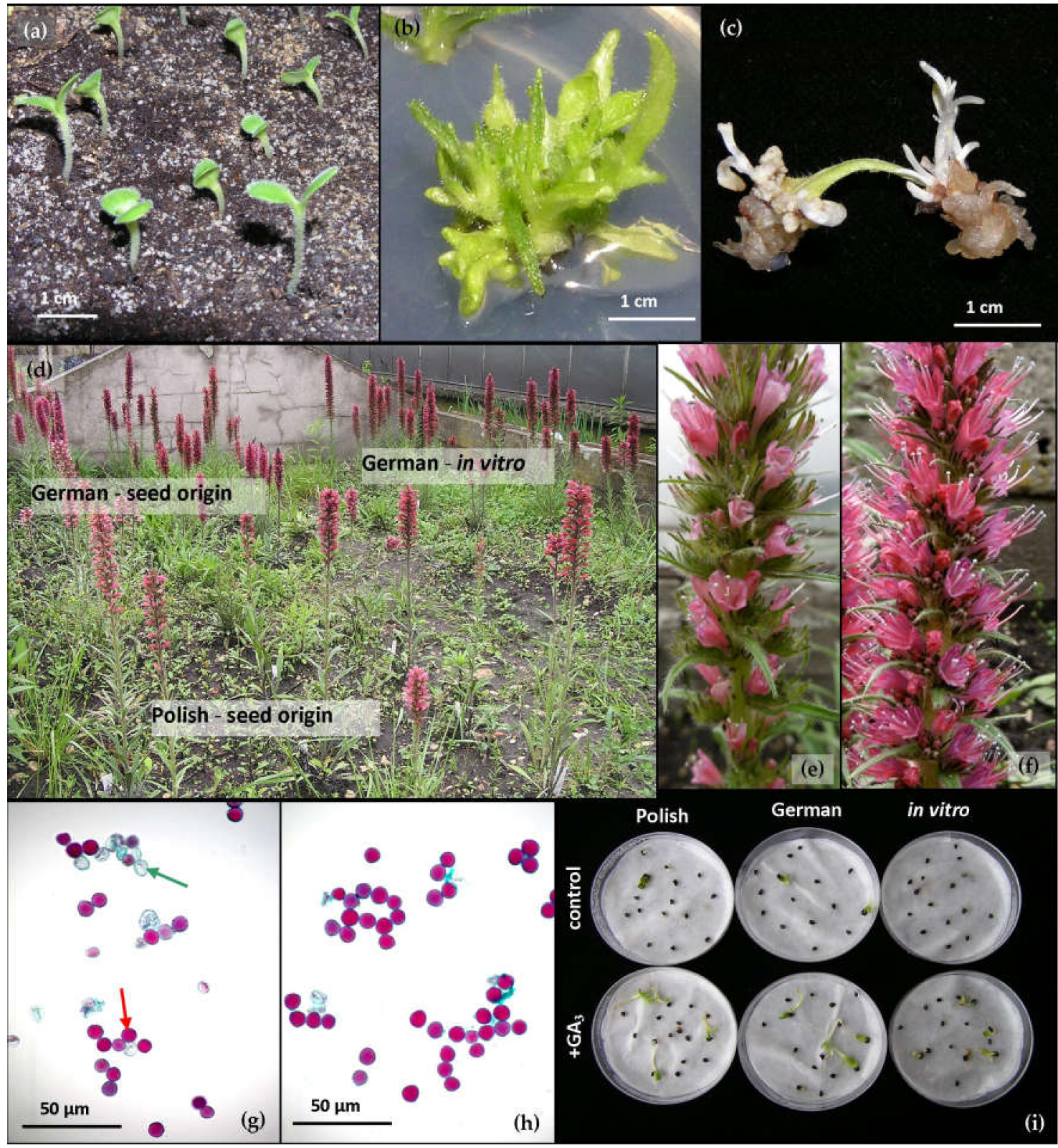

Figure 1. Pontechium maculatum: (a) German-origin seedlings; (b) shoots after three weeks of cultivation on multiplication medium Murashige and Skoog (MS) supplemented with $0.05 \mathrm{mg} \mathrm{L}^{-1}$ IBA and $0.25 \mathrm{mg} \mathrm{L}^{-1} \mathrm{BAP}$; (c) leaf explants after four weeks of cultivation on medium MS $+0.1 \mathrm{mg} \mathrm{L}^{-1}$ $\mathrm{NAA}+0.5 \mathrm{mg} \mathrm{L}^{-1} \mathrm{BAP}$; (d) plants growing in collection; (e) inflorescence of Polish seed-origin plant; (f) inflorescence of seed-origin plant from Germany; pollen viability of Polish (g) and German (h) seed-origin plants; (i) germination of seeds in blotter test in the year of harvest five days after sowing. Green arrow: Dead pollen grains; red arrow: Viable pollen grains.

\subsection{In Vitro Propagation}

\subsubsection{Shoot Culture}

German-origin seeds were disinfected for $30 \mathrm{~s}$ in $70 \%$ ethanol solution and then in $\mathrm{HgCl}_{2}$ for $3.5 \mathrm{~min}$. After rinsing three times in sterile water they were sown onto a Murashige and Skoog (MS) medium [31] with the addition of $20 \mathrm{~g} \mathrm{~L}^{-1}$ of sucrose (Chempur, Piekary Ślaskie, Poland) and solidified with $8 \mathrm{~g}$ of agar (Agar-Agar S-0030, BTL, Łódź, Poland). After germination, the seedlings were cut and the excised shoots were put onto the MS medium supplemented with $1.0 \mathrm{mg} \mathrm{L}^{-1}$ of 
thiamine, $0.5 \mathrm{mg} \mathrm{L}^{-1}$ of nicotinic acid, $100 \mathrm{mg} \mathrm{L}^{-1}$ of myo-inositol, $2.0 \mathrm{mg} \mathrm{L}^{-1}$ of glycin, $30 \mathrm{~g} \mathrm{~L}^{-1}$ of sucrose, solidified with agar, pH 5.8 (basal medium); 6-benzyl-aminopurine (BAP) combined with IBA (indole-3-butiric acid) or NAA ( $\alpha$-naphthalene-acetic-acid) (Table 1$)$ were used as plant growth regulators at the stage of multiplication (multiplication media). In the preliminary rooting experiment, there was no spontaneous root induction noted on the MS medium without growth regulators. Therefore, the effect of auxins, $0.1 \mathrm{mg} \mathrm{L}^{-1}$ IAA (indole-3-acetic acid), IBA or NAA at the rooting stage was investigated (Table 2). All chemicals if not mentioned otherwise were manufactured by Sigma-Aldrich (Saint-Louis, MO, USA).

Table 1. Multiplication rate (number of shoots) and the quality of P. maculatum explants after four weeks of cultivation on an MS medium with plant growth regulators added.

\begin{tabular}{|c|c|c|c|c|c|c|}
\hline \multirow{2}{*}{$\begin{array}{c}\text { BAP } \\
\left(\mathrm{mg} \mathrm{L}^{-1}\right)\end{array}$} & \multicolumn{2}{|c|}{ Auxins $\left(\mathrm{mg} \mathrm{L}^{-1}\right)$} & \multirow{2}{*}{$\begin{array}{c}\text { Mean } \\
\text { Multiplication } \\
\text { Rate }\end{array}$} & \multirow{2}{*}{$\begin{array}{c}\text { Mean Height } \\
(\mathrm{mm})\end{array}$} & \multirow{2}{*}{$\begin{array}{c}\text { Mean Number } \\
\text { of Leaves Per } \\
\text { Shoot }\end{array}$} & \multirow{2}{*}{$\begin{array}{c}\text { Vitrification } \\
(\%)\end{array}$} \\
\hline & IBA & NAA & & & & \\
\hline- & - & - & $8.9 b^{*}$ & $12.3 \mathrm{a}$ & $3.4 \mathrm{a}$ & $9.1 \mathrm{a}$ \\
\hline 0.1 & 0.05 & - & $5.2 \mathrm{ab}$ & $18.7 \mathrm{a}$ & $6.2 \mathrm{a}$ & $22.8 \mathrm{a}$ \\
\hline 0.25 & - & 0.05 & $5.6 \mathrm{ab}$ & $15.4 \mathrm{a}$ & $4.8 \mathrm{a}$ & $19.9 \mathrm{a}$ \\
\hline 1.5 & 0.1 & - & $4.9 \mathrm{a}$ & $14.6 \mathrm{a}$ & $4.9 \mathrm{a}$ & $6.8 \mathrm{a}$ \\
\hline 0.5 & - & 0.1 & $4.4 \mathrm{a}$ & $21.7 \mathrm{a}$ & $4.8 \mathrm{a}$ & $18.6 \mathrm{a}$ \\
\hline
\end{tabular}

$\mathrm{a}, \mathrm{b}$ * values within columns followed by the same letter do not differ significantly for $p \leq 0.5$.

Table 2. Rooting and the quality of $P$. maculatum explants after four weeks of cultivation on MS medium with auxins applied.

\begin{tabular}{cccccccc}
\hline $\begin{array}{c}\text { Auxin } \\
\left(\mathbf{m g ~ L}^{-1}\right)\end{array}$ & $\begin{array}{c}\text { Rooting } \\
\mathbf{( \% )}\end{array}$ & $\begin{array}{c}\text { Mean } \\
\text { Length of } \\
\text { Root }(\mathbf{m m})\end{array}$ & $\begin{array}{c}\text { Number } \\
\text { of Root }\end{array}$ & $\begin{array}{c}\text { Mean } \\
\text { Height } \\
\mathbf{( m m )}\end{array}$ & $\begin{array}{c}\text { Mean } \\
\text { Number } \\
\text { of Leaves } \\
\text { Per Shoot }\end{array}$ & $\begin{array}{c}\text { Vitrificatio } \\
\boldsymbol{n} \mathbf{( \% )}\end{array}$ & $\begin{array}{c}\text { Mean } \\
\text { Multiplication } \\
\text { Rate }\end{array}$ \\
\hline $0.1 \mathrm{IAA}$ & $63.8 \mathrm{a}{ }^{*}$ & $29.6 \mathrm{a}$ & $1.9 \mathrm{a}$ & $29.6 \mathrm{a}$ & $4.7 \mathrm{a}$ & $3.5 \mathrm{a}$ & $1.0 \mathrm{a}$ \\
$0.1 \mathrm{IBA}$ & $59.0 \mathrm{a}$ & $42.4 \mathrm{a}$ & $4.5 \mathrm{a}$ & $16.6 \mathrm{a}$ & $5.4 \mathrm{a}$ & $10.7 \mathrm{a}$ & $6.5 \mathrm{a}$ \\
$0.1 \mathrm{NAA}$ & $53.8 \mathrm{a}$ & $22.0 \mathrm{a}$ & $5.7 \mathrm{a}$ & $14.8 \mathrm{a}$ & $4.5 \mathrm{a}$ & $10.1 \mathrm{a}$ & $16.0 \mathrm{a}$ \\
\hline
\end{tabular}

$\mathrm{a}, \mathrm{b} *$ values within columns followed by the same letter do not differ significantly for $p \leq 0.5$.

Rosette explants, four-weeks old and approximately $1.0 \mathrm{~cm}$ high (for multiplication and rooting) with 4-5 leaves, were planted in $100 \mathrm{~mL}$ Erlenmeyer flasks that were kept in phytotrone with $16 / 8$ day/night and photon flux density of $70 \mu \mathrm{mol} \mathrm{m}^{-2} \mathrm{~s}^{-1}$ and temperature of $24 \pm 2{ }^{\circ} \mathrm{C}$.

Efficacy of multiplication (multiplication rate expressed as number of newly developed shoots) and rooting (percentage of rooted shoots, length and number of roots) and quality of plants (height, number of leaves, vitrification) were assessed at the end of each four-week passage. In each combination there were five flasks with six explants, and the experiment was repeated three times. Samples from 20 shoots were collected for ploidy assessment.

After multiplication and rooting, the plants were replanted in pots and after acclimatization they were cultivated in open field conditions for one season. The acclimatization was carried out for four weeks in Sanyo vegetative chambers, under 16/8 h day/night photoperiod and photon flux density of $60 \mu \mathrm{mol} \mathrm{m} \mathrm{m}^{-2} \mathrm{~s}^{-1}$, at $22 / 20^{\circ} \mathrm{C}$, with humidity gradually decreasing from $90 \%$ to $55 \%$, and then in a non-heated greenhouse.

\subsubsection{Indirect Organogenesis}

Fragments of leaves $1.0 \mathrm{~cm}$ long excised from shoots cultivated on a basal medium without plant growth regulators were placed on a basal medium supplemented with BAP, IBA, NAA or IAA and $\mathrm{GA}_{3}$ in various combination (Table 3 ) and cultivated for five weeks in photoperiod conditions and photon flux density of $70 \mu \mathrm{mol} \mathrm{m}{ }^{-2} \mathrm{~s}^{-1}$ or in continuous darkness. There were six explants placed with the abaxial side in contact with the medium in one $100 \mathrm{~mL}$ Erlenmeyer flask, with five flasks 
for each combination, and the experiment was repeated three times. At the end of the subculture, the percentage of callusing and regenerating explants was estimated together with the number of regenerating adventitious buds/shoots per explant. Twenty randomly chosen shoots were isolated and cultivated on a basal medium for ploidy assesment.

Table 3. Effect of media and light conditions on the morphogenetic response of leaf explants of Pontechium maculatum after five weeks of culture on media supplemented with different plant growth regulators $\left(\mathrm{mg} \mathrm{L}^{-1}\right)$.

\begin{tabular}{|c|c|c|c|c|c|c|c|}
\hline \multirow[b]{2}{*}{$\begin{array}{l}\text { Light } \\
\text { Conditions }\end{array}$} & \multicolumn{6}{|c|}{ Medium } & \multirow[b]{2}{*}{ Mean } \\
\hline & MS & $\begin{array}{c}\text { MS } \\
+0.1 \text { IBA } \\
+0.5 \text { BAP }\end{array}$ & $\begin{array}{c}\text { MS } \\
+0.05 \text { IBA } \\
+0.2 \text { BAP }\end{array}$ & $\begin{array}{c}\text { MS } \\
+0.1 \text { NAA } \\
+0.5 \text { BAP }\end{array}$ & $\begin{array}{c}\text { MS } \\
+0.1 \text { IAA } \\
+0.05 \text { BAP }\end{array}$ & $\begin{array}{c}\text { MS } \\
+0.1 \text { IAA } \\
+0.05 \text { BAP } \\
+0.5 \mathrm{GA}_{3}\end{array}$ & \\
\hline \multicolumn{8}{|c|}{ Percent of callusing explants } \\
\hline Photoperiod & $0.0 \mathrm{a}^{*} \pm 0.0$ & $0.0 \mathrm{a} \pm 0.0$ & $0.0 \mathrm{a} \pm 0.0$ & $0.0 \mathrm{a} \pm 0.0$ & $0.0 \mathrm{a} \pm 0.0$ & $0.0 \mathrm{a} \pm 0.0$ & $0.0 \mathrm{~A}$ \\
\hline Darkness & $23.1 \mathrm{c} \pm 17.0$ & $14.6 \mathrm{~cd} \pm 4.9$ & $16.7 b c \pm 6.9$ & $9.0 \mathrm{ab} \pm 4.8$ & $57.5 \mathrm{~d} \pm 10.5$ & $0.0 \mathrm{a} \pm 0.0$ & $20.1 \mathrm{~B}$ \\
\hline Mean & $11.6 \mathrm{~B}$ & 7.3 $\mathrm{AB}$ & $8.4 \mathrm{AB}$ & $4.5 \mathrm{AB}$ & $28.8 \mathrm{C}$ & $0.0 \mathrm{~A}$ & \\
\hline \multicolumn{8}{|c|}{ Percent of explants with organogenesis } \\
\hline Photoperiod & $0.0 \mathrm{a} \pm 0.0$ & $0.0 \mathrm{a} \pm 0.0$ & $0.0 \mathrm{a} \pm 0.0$ & $0.0 \mathrm{a} \pm 0.0$ & $0.0 \mathrm{a} \pm 0.0$ & $30.0 \mathrm{~b} \pm 21.5$ & $5.0 \mathrm{~A}$ \\
\hline Darkness & $29.9 \mathrm{~b} \pm 12.1$ & $85.4 \mathrm{~d} \pm 4.9$ & $83.3 \mathrm{~d} \pm 6.8$ & $82.1 \mathrm{~d} \pm 9.6$ & $42.5 b c \pm 10.5$ & 65. $5 c d \pm 22.7$ & $64.7 \mathrm{~B}$ \\
\hline Mean & $14.9 \mathrm{~A}$ & $42.7 \mathrm{~B}$ & $41.7 \mathrm{~B}$ & $41.1 \mathrm{~B}$ & $21.3 \mathrm{~A}$ & $47.8 \mathrm{~B}$ & \\
\hline \multicolumn{8}{|c|}{ Mean number of buds per explants (pcs) } \\
\hline Photoperiod & $0.0 \mathrm{a} \pm 0.0$ & $0.0 \mathrm{a} \pm 0.0$ & $0.0 \mathrm{a} \pm 0.0$ & $0.0 \mathrm{a} \pm 0.0$ & $0.0 \mathrm{a} \pm 0.0$ & $2.4 \mathrm{bc} \pm 0.9$ & $0.4 \mathrm{~A}$ \\
\hline Darkness & $1.0 \mathrm{ab} \pm 0.6$ & $6.3 \mathrm{e} \pm 1.6$ & $3.8 \mathrm{~cd} \pm 1.4$ & $4.9 \mathrm{de} \pm 1.7$ & $3.3 \mathrm{~cd} \pm 0.7$ & $3.1 \mathrm{~cd} \pm 1.3$ & $3.7 \mathrm{~B}$ \\
\hline Mean & $0.5 \mathrm{~A}$ & $3.2 \mathrm{C}$ & $1.9 \mathrm{BC}$ & $2.5 \mathrm{BC}$ & $1.7 \mathrm{AB}$ & $2.8 \mathrm{BC}$ & \\
\hline
\end{tabular}

$a, b, c, d, e, A, B, C *$ values within columns and rows followed by the same letter do not differ significantly for $p \leq 0.5$.

\subsubsection{Ploidy Assessment}

Plant ploidy analysis based on flow cytometry was performed in the Cytogenetics Laboratory of the Sugar Beet Breeding Station in Kutno (Poland). The ploidy level was determined for samples of young leaves collected separately from each plant (those from proliferated shoot culture and shoots regenerated on callus) and prepared according to the Galbraith method [32] modified by Thiem and Śliwińska [33]. Chopped plant material in $2 \mathrm{~mL}$ of lysis buffer with the addition of fluorochrome dye DAPI was filtered and analyzed using a PAII (Partec, Münster, Germany) cytometer. In each sample 720-1100 nuclei were assessed. The seed-origin plant from Germany served as a reference.

\subsection{Comparison of Generative Potential of Plants in Open Field Study}

After overwintering, during the following spring the seed-origin plants from Poland and from Germany and plants from in vitro shoot cultures were planted in groups of 15-19 in comparable habitat conditions at the collection of the university.

Over three successive vegetative years, the number of vegetative rosettes, the number of inflorescences (IP) and their length, and the number of cymeses in inflorescence (CI) were assessed. The number of flowers in cymeses (FIC) and the number of seeds set per fruit (SFr) were estimated for 30 randomly chosen cymeses or fruits from the middle section of inflorescences in each group. The data was used for the calculation of the actual production of seeds (AP), in particular plant groups, expressed as the number of seeds set per one flowering plant; one specimen was treated as repetition. Potential ability for seed production (PP) was estimated assuming that in each flower one fruit splits into four one-seed mericarps. The efficacy of seed setting was estimated as a ratio of actual production (AP) to a potential one (PP).

In the blooming period, pollen viability was assessed by the staining method [34]. In each examined group of plants, three mixtures of pollen taken from five different plants were assessed. 
In each preparation sample, microscopic analysis was conducted for 250-300 pollen grains; evaluation was done in three consecutive vegetative seasons.

The plants set fruit in open pollination conditions. Seeds were collected from all harvested fruit and immediately after the harvest their ability to germinate was assessed in the blotter test. Part of the seeds was soaked in $1.8 \mathrm{mM}$ gibberellin $\left(\mathrm{GA}_{3}\right)$ solution for $24 \mathrm{~h}$ before placing them on tissue paper. There were six Petri dishes in combination $\left(+\mathrm{GA}_{3}\right.$, control), with 15 seeds each. Dishes were kept at a temperature of $24 \pm 2{ }^{\circ} \mathrm{C}$ for four weeks under photoperiod conditions.

The remaining seeds collected from plants were also stored at $20^{\circ} \mathrm{C}$ and their ability to germinate was assessed after one and two year periods.

The observations carried out for one-year-old seeds allowed for the investigation of dynamics of their germination in all investigated groups of plants.

\subsection{Statistical Analysis}

The results were evaluated with ANOVA and Tukey's test at $p \leq 0.05$, treating one Petri dish, one flask, one plant or pollen mixture from five plants as a repetition. The percentage of flowering specimens was compared using multiway contingency tables and chi-square test. Statistical analyses were done using Statistica 13 (StatSoft Inc., Tulsa, OK, USA).

\section{Results}

\subsection{In Vitro Propagation}

\subsubsection{Shoot Culture}

The multiplication rate of P. maculatum observed for all media was over four and was the highest on the medium without growth regulators (Figure 1b). The quality of the obtained plants was comparable. Worth mentioning is the high percentage of plants with vitrification, even on a medium with no growth regulators added (Table 1 ).

The rooting ability of shoots was comparable regardless of the auxin being used (ca. 53-63\%). Rooted plants had similar length of root system as well as shoot height (Table 2). The plants on media supplemented with NAA or IBA maintained multiplication ability, which was not noted for plants on IAA medium. Out of 20 plantlets selected for ploidy assessment, 15 specimens that survived acclimatization and had the same DNA content as seed-origin plants were grown in pots under open field conditions.

\subsubsection{Indirect Organogenesis}

Callus tissue developed as early as within five to seven days of cultivation both on distal and proximal cut edges and numerous adventitious shoots started to differentiate, develop and grow. Continuous darkness positively affected both the efficiency of callus induction and the process of differentiation of adventitious buds, which took the form of indirect organogenesis in all cases. The addition of plant regulators was beneficial for regeneration because it increased the percentage of regenerating explants and the number of developing buds compared to the medium without growth regulators. The highest regeneration (over $80 \%$ ) was noted in media supplemented with either 0.5 or $0.2 \mathrm{mg} \mathrm{L}^{-1}$ of BAP. The addition of gibberellic acid $\left(\mathrm{GA}_{3}\right)$ improved regeneration abilities and it was the only medium on which the adventitious buds developed in photoperiod conditions (Table 3, Figure 1c); $\mathrm{GA}_{3}$ also prevented explants cultivated in the photoperiod from browning. Explants cultivated on the other media in photoperiod conditions turned brown within two weeks of culture.

\subsection{Ploidy Assessment}

Results of flow cytometric analysis presented on DNA histograms (Figure 2) showed a distribution of relative DNA content with dominant peaks corresponding to the $2 \mathrm{C}$ level in the G1 phase of the cell 
cycle of the seed-origin plant from Germany (control plant, Figure 2a); in vitro-origin after indirect organogenesis is shown in Figure $2 b$ and shoot culture in Figure 2c. The DNA content analyzed for all plants after indirect organogenesis indicated that they did not differ from seed-origin plants, while among plants after shoot culture two specimens turned out to have DNA content two times higher. These two plants were not assessed in the collection because they did not survive during first winter in the field conditions

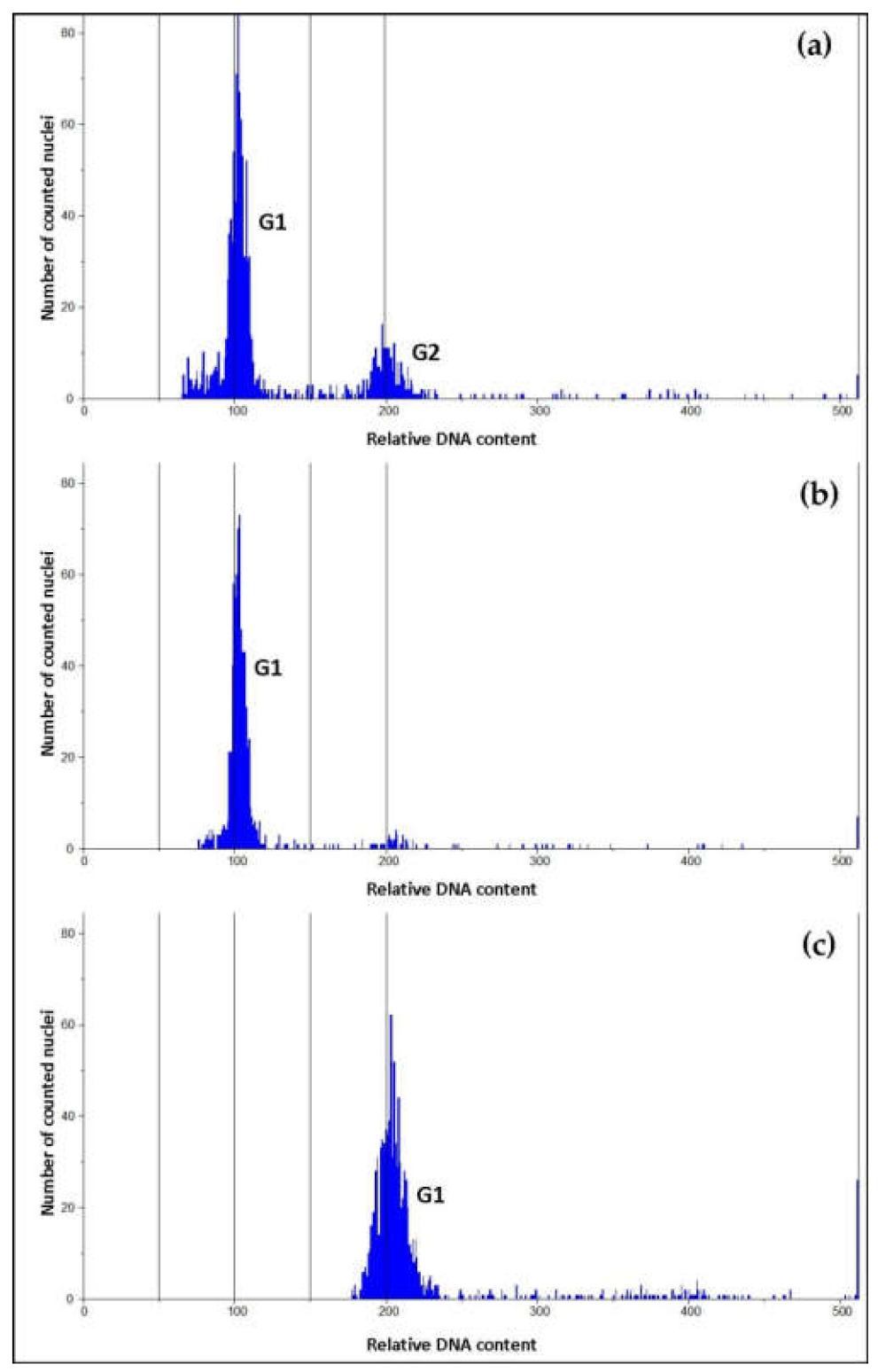

Figure 2. Histograms of relative DNA content in the nuclei of Pontechium maculatum leaf cells: (a) Control seed-origin plant from Germany; (b) plant originating from in vitro (indirect organogenesis); (c) one of two plants originating from shoot culture with doubled DNA content. $G_{1}, G_{2}$-phases of cell life.

\subsection{Comparison of Generative Potential of Plants in Open Field Study}

All of the P. maculatum plants were perennials (Figure 1d)—only one specimen from the German group died in the second year. The number of descendant rosettes developed from buds on the roots of mother plants was comparable in all groups.

In the first year only the plants originating from Poland developed vegetative rosettes. However, in the second year in vitro plants from Germany began to grow more intensively. The number of blooming specimens varied in the consecutive seasons due to different weather conditions. However, 
on average the lowest number of blooming specimens was among Polish-origin plants. They also developed the fewest inflorescences (Table 4).

Potential production of seeds (PP) varied between seasons, but on average the highest was for German plants of seed origin. In the other two groups, this potential was lower, which was the result of different factors: In in vitro-origin plants it was caused by a smaller number of flowers in cymeses, and in Polish-origin plants due to the smaller number of cymeses in inflorescences.

It was also noted that flowers on plants representing the Polish population had less vivid color of corolla (Figure 1e,f).

Additionally, the observed efficacy of seed setting for plant from in vitro was $18.8 \%$ and from Poland 26.8\%, which was lower than for seed-origin plants from Germany. This means that worse features crucial for potential and actual ability for generative propagation were noticed for Polish-origin plants and for in vitro-origin plants (Tables 4-6). Generally, the efficacy of seed setting noted for plants in all groups was low. 
Table 4. The number of vegetative rosettes, the percentage of flowering plants, the number and length of inflorescences of $P$. maculatum plants depending on their origin.

\begin{tabular}{|c|c|c|c|c|c|c|c|c|c|c|c|c|c|c|c|c|}
\hline \multirow{2}{*}{ Plant Origin } & \multicolumn{4}{|c|}{$\begin{array}{c}\text { Mean Number of Vegetative } \\
\text { Rosettes Per Plant }\end{array}$} & \multicolumn{4}{|c|}{ Flowering Specimens ** (\%) } & \multicolumn{4}{|c|}{$\begin{array}{c}\text { Mean Number of Inflorescences Per } \\
\text { Flowering Plant IP }\end{array}$} & \multicolumn{4}{|c|}{ Length of Inflorescences (cm) } \\
\hline & 2013 & 2014 & 2015 & Mean & 2013 & 2014 & 2015 & Mean & 2013 & 2014 & 2015 & Mean & 2013 & 2014 & 2015 & Mean \\
\hline $\begin{array}{l}\text { Polish—seed } \\
\text { origin }\end{array}$ & $2.2 \mathrm{ab}^{*}$ & $3.7 \mathrm{ab}$ & $3.2 \mathrm{ab}$ & $3.0 \mathrm{~A}$ & 77.8 a & $44.4 \mathrm{a}$ & $61.1 \mathrm{a}$ & $61.1 \mathrm{~A}$ & $1.6 \mathrm{a}$ & $3.3 \mathrm{ab}$ & $3.9 \mathrm{ab}$ & $2.8 \mathrm{~A}$ & $12.7 \mathrm{a}$ & $18.2 \mathrm{a}$ & $18.8 \mathrm{a}$ & $16.1 \mathrm{~A}$ \\
\hline $\begin{array}{l}\text { German-seed } \\
\text { origin }\end{array}$ & $0.0 \mathrm{a}$ & $5.5 \mathrm{~b}$ & $5.0 \mathrm{~b}$ & $3.7 \mathrm{~A}$ & $100 \mathrm{a}$ & $33.3 \mathrm{a}$ & $92.3 \mathrm{~b}$ & $\begin{array}{c}75.2 \\
\mathrm{AB}\end{array}$ & $2.9 \mathrm{ab}$ & $2.6 \mathrm{ab}$ & $7.8 \mathrm{ab}$ & $4.8 \mathrm{~B}$ & $17.7 \mathrm{a}$ & $18.0 \mathrm{a}$ & $21.4 \mathrm{a}$ & $16.6 \mathrm{~A}$ \\
\hline German-in vitro & $0.0 \mathrm{a}$ & $5.3 \mathrm{~b}$ & $3.9 \mathrm{ab}$ & $3.1 \mathrm{~A}$ & $100 \mathrm{a}$ & $77.8 \mathrm{a}$ & $100 \mathrm{~b}$ & $\begin{array}{c}92.6 \\
\mathrm{AB}\end{array}$ & $3.8 \mathrm{ab}$ & $3.6 \mathrm{ab}$ & $6.2 \mathrm{ab}$ & $4.6 \mathrm{AB}$ & $19.7 \mathrm{a}$ & $14.9 \mathrm{a}$ & $15.1 \mathrm{a}$ & $19.2 \mathrm{~A}$ \\
\hline Mean & $0.9 \mathrm{~A}$ & $4.7 \mathrm{~B}$ & $4.2 \mathrm{~B}$ & & $90.4 \mathrm{~B}$ & $47.6 \mathrm{~A}$ & 80.9 B & & $2.6 \mathrm{~A}$ & $3.2 \mathrm{~A}$ & $6.1 \mathrm{~B}$ & & $16.3 \mathrm{~A}$ & $17.4 \mathrm{~A}$ & $19.8 \mathrm{~A}$ & \\
\hline
\end{tabular}

$\mathrm{a}, \mathrm{b}, \mathrm{A}, \mathrm{B} *$ values within columns and rows for number of vegetative rosettes, inflorescence per flower and length of inflorescence followed by the same letter do not differ significantly for $p \leq 0.5$. ${ }^{* *}$ for $2013 p=0.05248$; for $2014 p=0.10117$; for $2015 p=0.01654$; means for plant origin $p=0.00536$; means for years $p=0.00002$.

Table 5. The number of cymes per inflorescence and per plant, the number of flowers in cymes, the number of seeds set per one fruit of $P$. maculatum plants depending on their origin.

\begin{tabular}{|c|c|c|c|c|c|c|c|c|c|c|c|c|c|c|c|c|}
\hline \multirow[t]{2}{*}{ Plant Origin } & \multicolumn{4}{|c|}{$\begin{array}{c}\text { Mean Umber of Cymes Per } \\
\text { Inflorescence } \\
\text { CI }\end{array}$} & \multicolumn{4}{|c|}{$\begin{array}{l}\text { Mean Number of Cymes Per Plant } \\
\qquad \text { CP }=\text { IP } \times \text { CI }\end{array}$} & \multicolumn{4}{|c|}{$\begin{array}{l}\text { Mean Number of Flowers in Cymes } \\
\text { FIC }\end{array}$} & \multicolumn{4}{|c|}{$\begin{array}{l}\text { Number of Seeds Set per One Fruit } \\
\text { SFr }\end{array}$} \\
\hline & 2013 & 2014 & 2015 & Mean & 2013 & 2014 & 2015 & Mean & 2013 & 2014 & 2015 & Mean & 2013 & 2014 & 2015 & Mean \\
\hline Polish—seed & 42.4 & 23.3 & 40.6 & 37.1 & 63.4 & 74.7 & 186 & & 9.1 & 7.0 & 7.7 & 8.0 & 0.9 & 1.3 & 0.98 & 1.0 \\
\hline origin & $a^{*}$ & $\mathrm{a}$ & $\mathrm{a}$ & A & $\mathrm{a}$ & $\mathrm{a}$ & $\mathrm{ab}$ & 107.0A & $\mathrm{b}$ & $\mathrm{ab}$ & $\mathrm{ab}$ & B & $\mathrm{a}$ & $\mathrm{ab}$ & $\mathrm{ab}$ & $\mathrm{AB}$ \\
\hline German-seed & 63.5 & 40.9 & 47.9 & 53.9 & 172.6 & 76.4 & 411.9 & $252.3 \mathrm{~B}$ & 8.2 & 9.6 & 6.8 & 8.0 & 0.8 & 1.6 & 1.20 & 1.1 \\
\hline origin & $\mathrm{b}$ & $\mathrm{a}$ & $\mathrm{a}$ & B & $a b$ & $a b$ & $\mathrm{~b}$ & $252.3 \mathrm{~B}$ & $\mathrm{~b}$ & $\mathrm{~b}$ & $a b$ & B & $\mathrm{a}$ & $\mathrm{b}$ & $a b$ & B \\
\hline \multirow{2}{*}{ German-in vitro } & 68.3 & 44.6 & 38.6 & 50.2 & 229. & 130.7 & 259.9 & & 4.42 & 7.1 & 5.9 & 5.8 & 0.6 & 0.8 & 0.88 & 0.8 \\
\hline & $\mathrm{b}$ & $\mathrm{a}$ & a & $\mathrm{AB}$ & $\mathrm{ab}$ & $\mathrm{ab}$ & $\mathrm{ab}$ & 212.1AB & a & $\mathrm{ab}$ & $a b$ & A & $\mathrm{a}$ & $\mathrm{a}$ & a & A \\
\hline Mean & $56.4 \mathrm{~B}$ & $35.1 \mathrm{~A}$ & $42.9 \mathrm{~A}$ & & $143.6 \mathrm{~A}$ & $94.7 \mathrm{~A}$ & $295.1 \mathrm{~B}$ & & $7.3 \mathrm{~A}$ & $7.9 \mathrm{~A}$ & $6.8 \mathrm{~A}$ & & $0.8 \mathrm{~A}$ & $1.1 \mathrm{~B}$ & $1.0 \mathrm{AB}$ & \\
\hline
\end{tabular}

* explanation: See Table 4. IP-number of inflorescences per flowering plant (Table 4). 
Table 6. Potential seed production and efficacy of seed setting of P. maculatum plants depending on their origin.

\begin{tabular}{|c|c|c|c|c|c|c|c|c|c|c|c|c|}
\hline \multirow{2}{*}{ Plant Origin } & \multicolumn{4}{|c|}{$\begin{array}{c}\text { Number of Seeds Set Per Flowering Plant } \\
\qquad \mathrm{AP}=\mathrm{CP} \times \mathrm{FlC} \times \mathrm{SFr}\end{array}$} & \multicolumn{4}{|c|}{$\begin{array}{l}\text { Potential Seed Production Per Flowering Plant } \\
\qquad P=C P \times \text { FlC } \times 4\end{array}$} & \multicolumn{4}{|c|}{ Efficacy of Seed Set (\%) } \\
\hline & 2013 & 2014 & 2015 & Mean & 2013 & 2014 & 2015 & Mean & 2013 & 2014 & 2015 & Mean \\
\hline Polish—seed origin & $490.0 \mathrm{a} *$ & $679.3 a$ & $1403.6 \mathrm{ab}$ & $840.4 \mathrm{~A}$ & $2305.9 a$ & $2090.2 a$ & $5208.3 a$ & $3221.1 \mathrm{~A}$ & 21.3 & 32.5 & 27.0 & 26.8 \\
\hline German-seed origin & $1174.9 \mathrm{a}$ & $1196.1 \mathrm{ab}$ & $3361.0 \mathrm{~b}$ & 2093.3B & $5662.0 \mathrm{a}$ & $2935.3 a$ & $13180.6 b$ & 8210.7B & 20.8 & 40.8 & 25.5 & 29.0 \\
\hline German—in vitro & $628.9 a$ & 705.3a & $1349.4 \mathrm{ab}$ & $921.4 \mathrm{~A}$ & $4058.4 a$ & $3712.3 a$ & $6133.6 \mathrm{ab}$ & $4735.7 \mathrm{AB}$ & 15.5 & 19.0 & 22.0 & 18.8 \\
\hline Mean & 797.7A & 817. $6 \mathrm{~A}$ & 2159.9B & & $4045.4 \mathrm{~A}$ & $2869.2 \mathrm{~A}$ & 8601.2B & & 19.2 & 30.7 & 24.8 & \\
\hline
\end{tabular}

* explanation: See Table 4. CP—number of cymes per plant; FlC—number of flowers in cymes; SFr—number of seeds set per one fruit (Table 5); AP—actual production of seeds; $\mathrm{PP}-$ potential production of seeds. 


\subsubsection{Pollen Viability}

Pollen viability was within the $45-70 \%$ range. The results were diversified depending on the origin of the plants (Figure 1g,h). Pollen viability also varied in each consecutive season (Table 7).

Table 7. Viability of P. maculatum pollen depending on plant origin in the years 2013-2015.

\begin{tabular}{ccccc}
\hline \multirow{2}{*}{ Plant Origin } & \multicolumn{4}{c}{ Pollen Viability (\%) } \\
\cline { 2 - 4 } & $\mathbf{2 0 1 3}$ & $\mathbf{2 0 1 4}$ & $\mathbf{2 0 1 5}$ & Mean \\
\hline Polish-seed origin & $45.6 \mathrm{ab}^{*}$ & $48.1 \mathrm{ab}$ & $58.5 \mathrm{bcd}$ & $50.7 \mathrm{~A}$ \\
German-seed origin & $63.1 \mathrm{~cd}$ & $51.3 \mathrm{ab}$ & $70.2 \mathrm{~d}$ & $61.5 \mathrm{~B}$ \\
German-in vitro & $69.6 \mathrm{~d}$ & $44.8 \mathrm{a}$ & $87.8 \mathrm{e}$ & $67.4 \mathrm{C}$ \\
Mean & $59.4 \mathrm{~B}$ & $48.0 \mathrm{~A}$ & $72.1 \mathrm{C}$ & \\
\hline
\end{tabular}

$\mathrm{a}, \mathrm{b}, \mathrm{c}, \mathrm{d}, \mathrm{e}, \mathrm{A}, \mathrm{B}, \mathrm{C}^{*}$ values within columns and rows followed by the same letter do not differ significantly for $p \leq$ 0.5 .

\subsubsection{Germination Ability of Seeds}

The ability of seeds collected from plants of different origin to germinate in the year of harvest was comparable and was in the 56-68\% range. This ability was higher for seeds that were stored for one year and was within $64-78 \%$, being comparable for each type of seed. However, seeds collected from in vitro plants after storage for two years had a lower germination rate than seeds collected from seed-origin plants regardless of their origin. Because the application of gibberellin did not improve the germination ability in this case, it can be assumed that these seeds began to lose their vitality, quite different than seeds from plants of seed origin.

The beneficial influence of gibberellin on germination ability was noticed for seeds assessed in the year of harvest. It increased the percentage of germinating seeds (Figures 1i and 3; Table 8), without significant influence on the dynamics of germination: Most seeds germinated by eighth day, with the exception of German seeds without gibberellin treatment and Polish-origin plants treated with $\mathrm{GA}_{3}$. In those groups germination took place up to 28 days after sowing.

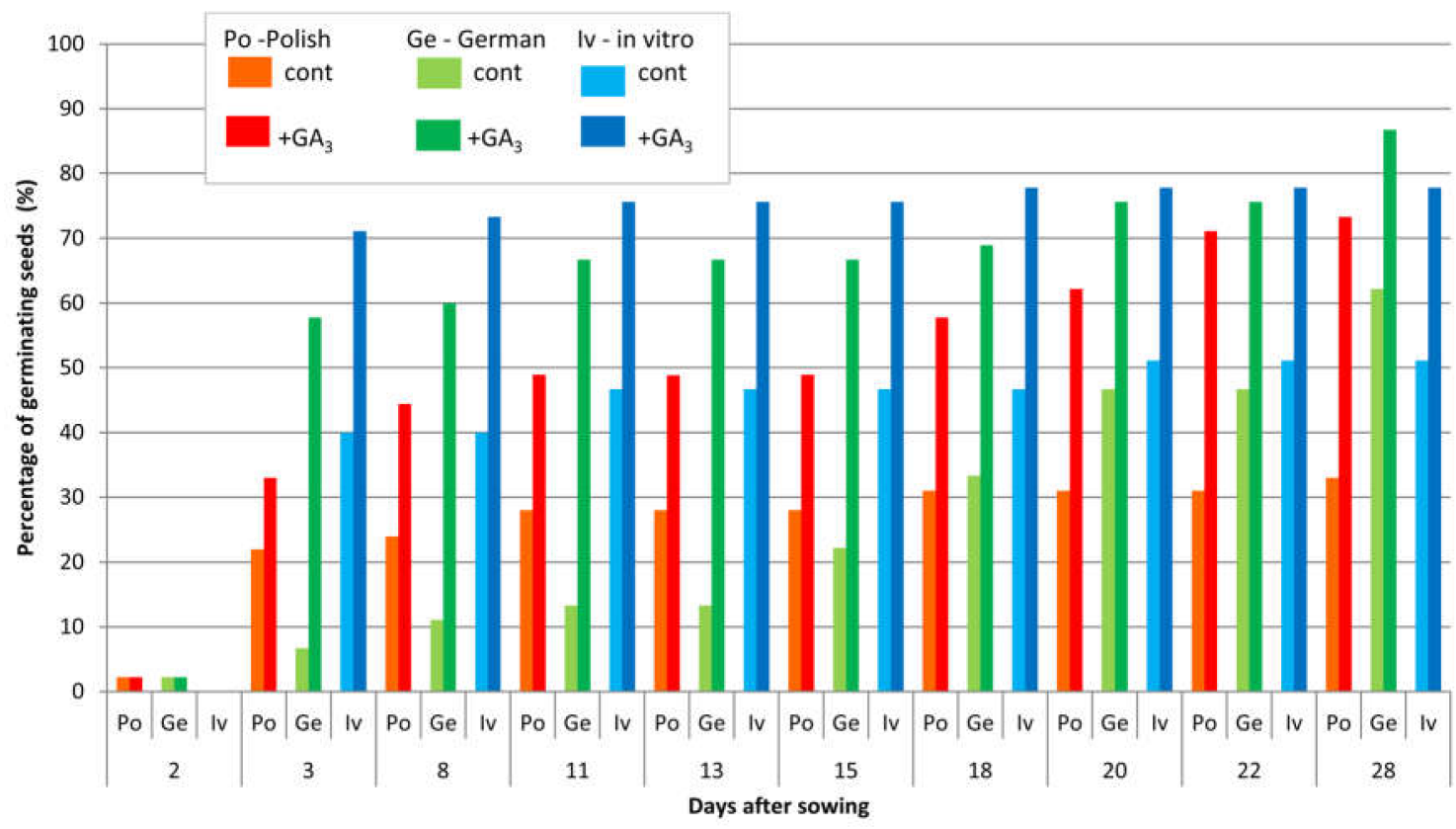

Figure 3. Influence of $\mathrm{GA}_{3}$ treatment on germination dynamics of Pontechium maculatum seeds of different origin in the year of harvest. (Ge)_German seed-origin plants; (Po)_Polish seed-origin plants; (Iv)—German in vitro-origin plants; (cont)—control without $\mathrm{GA}_{3}$ pretreatment; $\left(+\mathrm{GA}_{3}\right)$ —seeds with gibberellin pretreatment. 
Table 8. Germination ability of P. maculatum seeds depending on their origin and gibberellin treatment in three consecutive years after harvest (\%).

\begin{tabular}{cccc}
\hline Plant Origin & Control & $+\mathrm{GA}_{3}$ & Mean \\
\hline & In the year of harvest & \\
\hline Polish—seed origin & $41.7 \mathrm{a}$ & $71.6 \mathrm{ab}$ & $56.6 \mathrm{~A}$ \\
German-seed origin & $53.3 \mathrm{ab}$ & $83.3 \mathrm{~b}$ & $68.3 \mathrm{~A}$ \\
German-in vitro & $48.4 \mathrm{a}$ & $73.6 \mathrm{ab}$ & $61.0 \mathrm{~A}$ \\
Mean & $47.8 \mathrm{~B}$ & $76.2 \mathrm{~A}$ & \\
\hline \multicolumn{4}{c}{ One year after harvest } \\
\hline Polish—seed origin & $74.0 \mathrm{a}$ & $81.1 \mathrm{a}$ & $77.8 \mathrm{~A}$ \\
German-seed origin & $72.2 \mathrm{a}$ & $77.8 \mathrm{a}$ & $75.0 \mathrm{~A}$ \\
German-in vitro & $58.9 \mathrm{a}$ & $69.7 \mathrm{a}$ & $64.3 \mathrm{~A}$ \\
Mean & $76.2 \mathrm{~A}$ & $68.5 \mathrm{~A}$ & \\
\hline & Two years after harvest & $87.7 \mathrm{~B}$ \\
\hline Polish—seed origin & $88.7 \mathrm{~b}$ & $86.7 \mathrm{~b}$ & $86.7 \mathrm{~B}$ \\
German-seed origin & $73.3 \mathrm{~b}$ & $100 \mathrm{~b}$ & \\
German-in vitro & $46.6 \mathrm{a}$ & $46.6 \mathrm{a}$ & $\mathrm{A}$ \\
Mean & $69.5 \mathrm{~A}$ & $77.7 \mathrm{~A}$ & \\
\hline
\end{tabular}

$\mathrm{a}, \mathrm{b}, \mathrm{A}, \mathrm{B}$ * values within columns and rows for one vegetation season followed by the same letter do not differ significantly for $p \leq 0.5$.

\section{Discussion}

Effective propagation is a key factor for profitability of horticultural production and survival of species in their habitat. Propagation using seeds in commercial production could be most convenient, providing seed production is abundant, they are viable and easily germinate even after storage period. Additionally, in wild populations, effective generative propagation promotes adaptability of species. In turn, micropropagation is considered as a cloning technique resulting in numerous uniform specimens, which is a great advantage in horticulture.

Presented results for the first time describe selected aspects of generative propagation of P. maculatum, which is an endangered species in numerous countries. Efficiency of generative propagation was assessed between two European genetic resources of this species originating from Poland and Germany. The method of in vitro propagation from seeds and leaf explants was developed and obtained plants were evaluated for generative propagation changes generated in tissue culture.

As presented in this paper, a comprehensive procedure of propagation in shoot cultures from seeds is the first in vitro propagation method of Pontechium and Echium species with omission of the callus phase. The obtained multiplication coefficient makes it an efficient method. The best multiplication rate for $P$. maculatum was noted on the medium without growth regulators (8.9 shoots) or on the medium with $0.1 \mathrm{mg} \mathrm{L}^{-1}$ NAA designed for rooting (16 shoots). It seems that the species does not need cytokinins added to the medium to multiply. It can be the result of a high level of endogenic plant growth regulators and can be the result of natural abilities to develop vegetative rosettes. Cytokinins are produced mainly in roots [35] and this could be a reason that rooted plants multiplied better than cultivated shoots. The other species of the Boraginaceae family with a great multiplication rate have already been reported. The number of new developed shoots reached 7.1 for Heliotropium indicum Linn., 17.7 for Mertensia maritima L. and 20.1 for Arnebia benthamii Wall [36-38]; however, they multiplied on a media supplemented with auxins and cytokinins. It is debatable how long the ability of effective cloning without plant growth regulators would be sustained in continuous culture. Easy acclimatization together with great regenerative abilities of the species in the experimental conditions presented here makes tissue culture cloning an effective propagation method for examined species. 
Unlike shoot multiplication, the addition of plant growth regulators was beneficial for callus induction and organogenesis on leaf explants (Table 3). The callusing and regeneration were rapid and profuse on explants cultivated in darkness, whereas photoperiod conditions suppressed differentiation. This adverse effect of light is thought provoking, although darkness-promoting somatic embryogenesis [39], bulblet regeneration [40] and rooting [41] have been previously observed. It was also proved that early exposure to light can prevent callus formation and decrease adventitious shoot regeneration [42]. Light is the most important factor which regulates plant growth and development in vitro because it is involved in photomorphogenic responses [43]. For this reason, the mechanisms causing the negative influence of light on cultivated tissues can be complex and still poorly understood. We observed that leaf explants cultivated in photoperiod conditions were browning, which is a physiological disorder observed in many plant species during in vitro propagation [44]. It was reported that some explants release phenolic substances as secondary metabolites from cut surfaces. They can further oxidize and form quinone derivatives that can be toxic to the explants [45]. Moreover, light treatment during cultivation can be a reason of photooxidative stress responsible for the increased level of reactive oxygen species (ROS), which contribute to phenol oxidation [42]. The regeneration abilities of $P$. maculatum explants cultivated in photoperiod were improved when $\mathrm{GA}_{3}$ was added to the medium. It can be hypothesized that $\mathrm{GA}_{3}$ treatment activated some ROS scavengers to reduce oxidative stress or induced the increased accumulation of proteins and amino acids (e.g., proline), which can counteract stress symptoms. Recently published data demonstrated that GA controls certain physiological processes in response to stress [46] and the positive effect of gibberelline treatment on the antioxidant complex was described for Picea asperata Mast. [47].

The assessed ploidy level of plants resulting from shoot cultures and microshoots developing from adventitious buds on callus indicates that shoot cultivation induced variation, whereas it was not observed in the latter. Somaclonal variation occurring uncontrollably in tissue culture is more frequent usually in regenerants obtained from callus [48]. Our results show that P. maculatum is prone to variability caused by conditions of in vitro cultivation, even if the callus stage is omitted. Somaclonal variants were already reported in shoot cultures of different species [49-51]. This lack of genetic stability can be recognized as disadvantageous for conservation purposes. On the other hand, it is believed that it could be beneficial in the restitution of a small population $[52,53]$. Nevertheless, new genetic variation makes this propagation method a valuable source of new qualities potentially useful in horticulture.

In all assessed groups of $P$. maculatum, the plants were perennials which developed descendant rosettes and bloomed every year. Pollen viability ranging between $50.7 \%$ and $67.4 \%$ was lower than observed for E. vulgare L. [54]. Notwithstanding, observed pollen viability was not the factor determining the efficacy of fruit setting (Table 5; Table 7). Depending on the plant group tested, plants of P. maculatum developed on average $0.8-1.1$ seeds from one flower in conditions of open-field pollination. That means that approximately one of four fruit mericarps contained a seed similarly as it was described for E. vulgare [55]. However, the observed germination ability was higher than that reported for E. vulgare [56,57]. The seeds of P. maculatum germinated rapidly and synchronously independently of $\mathrm{GA}_{3}$ treatment and their germination ability was sustained until the third year after harvest. The influence of gibberellin as a stimulating agent of germination of P. maculatum was limited to seeds sown in the year of harvest when it accelerated germination and in most cases enlarged the percentage of germinating seeds. This indicated the transition into post-harvest dormancy, which most likely ended after one year. $\mathrm{GA}_{3}$ applied one and two years after the harvest did not increase the germination ability of seeds. Gibberellin, natural phytohormone, is known for its ability to reduce seed dormancy time and successfully stimulated seed germination of other plants [58].

Comparison of two groups of P. maculatum (Polish and German) showed that they differ in the features that determine the potential and actual generative propagation ability. Altered structure of the inflorescence of Polish-origin plants restricted mainly their potential generative ability. Lower actual reproductive ability within this group was additionally exacerbated by decreased efficacy of fruit 
setting. The efficacy of seed setting in all compared groups was within $18.9-29 \%$, the highest in German seed-origin plants, the lowest in German in vitro-origin plants. Similar seed setting ability was described for E. vulgare (on average 0.91-1.7 per flower), varying for populations growing in different locations [55]. Such variation could be ascribed to both varied habitats and various, genetic-dependent, reproductive abilities.

In research presented here, P. maculatum plants were growing in comparable conditions, on adjacent plots. Thus, maternal effect and/or limited resources cannot be the reason of lower efficacy of seed setting by German in vitro plants and Polish-origin plants. The environment of the mother plant can affect the progeny features. Environmental maternal effects have been well documented for early developmental stages such as weight of seeds or their germination ability, but they usually vanish in later stages of the life cycle and in the next generation [59]. Nevertheless, maternal effects lasting for an entire life cycle [60] and even into the next generation [61] were also reported. However, it could be assumed that the selection of the same size seedlings of Russian bugloss in the presented research most likely eliminated diversity due to the maternal effect. Another cause of different reproductive abilities of compared P. maculatum types could be interpopulation genetic variation. This would indicate an unfavorable change within reproductive traits of Polish-origin plants.

For years Polish populations have been low in number. In addition, they are island populations, some 150-200 km away from the nearest located in Ukraine [62]. This limits interpopulation gene flow due to restricted seed dispersal and pollen transfer. Strong selection pressure in the face of biotic and abiotic conditions in particular locations can cause the emergence of ecotype with a set of characteristics vital to genetic distinctiveness [63]. The unique gene arrangements of these populations decided their survival and should be preserved during different biodiversity conservation programs. However, in the presence of selection pressure of isolated populations with limited exchange of genetic material, unfavorable phenomena can occur, influencing their intrapopulation genetic variability. Then, results of inbreeding depression, genetic erosion or genetic drift are pronounced [4,64]. Survival of such populations is questionable and the results of conducted research indicate that the state of the Polish population of $P$. maculatum restricts their reproductive and survival abilities.

Our results showed that, although in vitro plants of P. maculatum did not differ in number of descendant rossettes from German seed-origin plants (Figure 1d), cultivation in vitro restricted their generative propagation ability and effectiveness of setting seeds. Moreover, seeds collected from in vitro plants also lost their germination abilities earlier compared to the other groups. The differences were not of a transient nature and were sustained for three consecutive years. Changes resulting from tissue culture propagation in the case of P. maculatum were not favorable and were the effect of somaclonal variation occurring uncontrollably during tissue culture cultivation [48]. Because genetic fidelity assessed with the help of molecular techniques relates only to fragments of the genome, not necessarily connected with heredity, the comprehensive profile of plants obtained from micropropagation should also include ploidy assessment and, above all, quality characteristics. It is possible that, regardless of the proved genetic fidelity on the molecular level, the plants obtained from tissue culture will differ from mother plants in quality features [65]. It was also demonstrated that plants with altered genome posses the same reproductive capability as a mother plant and plants growing in natural populations [53]. The changes noticed in plants obtained from micropropagation could be permanent [66] or transient of epigenetic character $[30,67]$. There are also cases when some changes are permanent and others decline [68].

Propagation in tissue cultures is a way of obtaining a large number of plants in a short time from a small amount of available initial material. This makes such techniques extremely valuable in case of the propagation of plants which are rare but it is also commonly applied for cultivated crops. The wild resources of plants have genetic diversity useful for developing more productive, nutritious, ornamental or resilient crop cultivars, which can be enhanced by somaclonal variation of plant tissue culture. The results for $P$. maculatum indicate that this species can not only be efficiently propagated in vitro, but is also prone for spontaneous variation. 
In efforts aimed at augmentation of existing natural populations or creating secondary localities, it is recommended to use plants obtained from seeds from populations that have undergone protective treatment. This allows the preservation of the local ecotype which is best suited for local conditions and maintaining high biodiversity within the species. However, limited reproductive abilities of Polish-origin P. maculatum raises some doubts about its adaptive and survival abilities in the natural habitat.

Recently other options have been discussed when it comes to extremely small populations with little genetic variability. Falk and Holsinger [69] suggested to use seeds obtained from 3-5 populations in reintroduction. Vergeer et al. [70] recommended mixing non-local populations in case local populations with sufficient genetic variability are not available. It was also suggested to use similar ecological habitats as a source of seeds [71].

However, it always should be kept in mind that outbreeding depression can occur as a consequence of interpopulation crosses that decreases offspring conditions $[72,73]$. It should also be taken into account that existing gene arrangements can fail in environments struggling with climatic changes [74]. All that causes that planning of restitution efforts is very challenging. It requires a balance between the value of local adaptation with the need for future adaptation potential. Beside strict local provenancing of plant material used for restoration, the strategy matching future climate (i.e., predictive provenancing) should be taken into consideration. Different approaches of seed sourcing, depending on the availability and similarity of ecotypes, also taking into account the likelihood of negative outcomes such as outcrossing depression, have been already described: Relaxed local provenancing, composite provenancing and admixture provenancing $[5,6]$.

\section{Conclusions}

Pontechium maculatum plants can be effectively propagated by seeds; however, differences in this respect among available resources of this species appear. Irrespective of origin, the seeds have great germination ability which can be sustained for at least two years and after-harvest dormancy can be broken by $\mathrm{GA}_{3}$ treatment.

P. maculatum can be efficiently propagated using tissue culture techniques both from seeds in shoot culture or using secondary leaf explants through indirect organogenesis. In vitro cultivation induced variation which can be the source of new features. In vitro-origin plants can be used for horticulture and apiculture purposes, reducing overexploitation of natural resources.

P. maculatum is a rare species that requires the implementation of different active conservation programs. Presented results demonstrate that, within Polish populations of this species, deterioration of reproductive abilities occurred. Therefore, the dilemma that has to be grappled with is what source of plant material and which type of propagation for the restitution of P. maculatum should be used that permits both conservation of local biodiversity and sufficient reproduction capability necessary for its survival.

Author Contributions: Conceptualization, E.S. and B.N.; methodology, B.N. and E.S.; formal analysis, E.S. and J.A.; investigation, E.S. and B.N.; resources, B.N.; data curation, E.S.; writing-original draft preparation, B.N; writing - review and editing, E.S. and J.A.; funding, J.A. All authors have read and agreed to the published version of the manuscript.

Funding: This research was funded from a subsidy SUB/2019-0511000000-D507 of the Ministry of Science and Higher Education of the Republic of Poland aimed at maintenance and development of research potential of the Department of Botany, Physiology and Plant Protection. The APC was funded by the subsidy SUB/2020-050012-D011 from the same Ministry.

Acknowledgments: Authors are very grateful to Karolina Pieczonka for her assistance with data collection. The authors would like to thank B. Tokarz and E. Hanus-Fajerska for the proofreading of the revised manuscript.

Conflicts of Interest: The authors declare no conflict of interest. 


\section{References}

1. Heywood, V.; Casas, A.; Ford-Lloyd, B.; Kell, S.; Maxted, N. Conservation and sustainable use of crop wild relatives. Agric. Ecosyst. Environ. 2007, 121, 245-255. [CrossRef]

2. Conger, B.V. (Ed.) Cloning Agricultural Plants via in Vitro Techniques, 1st ed; CRC Press: Boca Raton, FL, USA, 1981; pp. 1-280. [CrossRef]

3. Gajewski, Z.; Boron, P.; Lenart-Boroń, A.; Nowak, B.; Sitek, E.; Mitka, J. Conservation of Primula farinosa in Poland with respect to the genetic structure of populations. Acta Soc. Bot. Pol. 2018, 87, 3577. [CrossRef]

4. Jones, T.A. When local isn't best. Evol. Appl. 2013, 6, 1109-1118. [CrossRef] [PubMed]

5. Bucharova, A.; Bossdorf, O.; Hölzel, N.; Kollmann, J.; Prasse, R.; Durka, W. Mix and match: Regional admixture provenancing strikes a balance among different seed-sourcing strategies for ecological restoration. Conserv. Gen. 2019, 20, 7-17. [CrossRef]

6. Havens, K.; Vitt, P.; Still, S.; Kramer, A.T.; Fant, J.B.; Schatz, K. Seed sourcing for restoration in an era of climate change. Nat. Areas J. 2015, 35, 122-133. [CrossRef]

7. Letz, R.; Uhríková, A.; Májovský, J. Chromosome number of several interesting taxa of the flora of Slovakia. Biologia 1999, 54, 43-49.

8. Hilger, H.H.; Böhle, U.R. Pontechium: A new genus distinct from Echium and Lobostemon (Boraginaceae). Taxon 2000, 49, 737-746. [CrossRef]

9. Chmielewski, P.; Czarnecka, B.; Kucharczyk., M. Echium russicum J.F.Gmel. Żmijowiec czerwony. In Polska Czerwona Księga Roślin. Paprotniki i rośliny kwiatowe [Polish plant red data book. Pteridophyta and Spermatophyta]; Kaźmierczakowa, R., Zarzycki, K., Mirek, Z., Eds.; Akademia Nauk: Kraków, Poland, 2014; pp. 417-418.

10. Chwil, M.; Weryszko-Chmielewska, E. Nectary structure and nectar secretion of Echium russicum J. F. GMEL. flowers. Acta Agrobot. 2007, 60, 25-33. [CrossRef]

11. Nicćiforović, N.; Mihailović, V.; Mašković, P.; Solujić, S.; Stojković, A.; Pavlović Muratspahić, D. Antioxidant activity of selected plant species; potential new sources of natural antioxidants. Food Chem. Toxicol. 2010, 48, 3125-3130. [CrossRef]

12. Dresler, S.; Kubrak, T.; Bogucka-Kocka, A.; Szymczak, G. Determination of shikonin and rosmarinic acid in Echium vulgare L. and Echium russicum J.F. Gmel. by Capillary Electrophoresis. J. Liq. Chromatogr. Rel. Technol. 2015, 38, 698-701. [CrossRef]

13. Olennikov, D.N.; Daironas, Z.; Zilfikarov, I.N. Shikonin and rosmarinic-acid derivatives from Echium russicum roots. Chem. Nat. Comd. 2017, 53, 953-955. [CrossRef]

14. Guil-Guerrero, J.L.; Garcia-Maroto, F.; Vilches-Ferron, M.A.; Lopez-Alonso, D. Gamma-linolenic acid from fourteen Boraginaceae species. Ind. Crops Prod. 2003, 18, 85-89. [CrossRef]

15. Batsatsashvili, K.; Mehdiyeva, N.; Fayvush, G.; Kikvidze, Z.; Khutsishvili, M.; Maisaia, I.; Sikharulidze, S.; Tchelidze, D.; Aleksanyan, A.; Alizade, V.M.; et al. Echium maculatum L. Boraginaceae. In Ethnobotany of the Caucasus. European Ethnobotany; Bussmann, R., Ed.; Springer: Cham, Germany, 2016; pp. 1-4. [CrossRef]

16. Vladimirov, V.; Dane, F.; Tan, K. New floristic records in the Balkans: 28. Phytol. Balc. 2015, 21, 367-399.

17. Zając, M.; Zając, A. Elementy Geo-Graficzne Rodzimej Flory Polski [The Geo-Graphical Elements of Native Flora of Poland]; Nakładem Pracowni Chorologii Komputerowej Instytutu Botaniki Uniwersytetu Jagiellońskiego: Kraków, Poland, 2009; p. 93.

18. Eliáš, P.J.; Dítě, D.; Kliment, J.; Hrivnák, R.; Feráková, V. Red list of ferns and flowering plants of Slovakia. Biologia 2015, 70, 218-228. [CrossRef]

19. Petrova, A.; Vladimirov, V. Red List of Bulgarian vascular plants. Phytol. Balc. 2009, 15, 63-94.

20. Cursach, J.; Rita, J. Implications of the reproductive biology of the narrow endemic Naufraga balearica (Apiaceae) for its conservation status. Plant Syst. Evol. 2012, 298, 581-596. [CrossRef]

21. Massey, J.R.; Whitson, P.D. Species biology, the key to plant preservation. Rhodora 1980, 82, 97-103.

22. Yankova-Tsvetkova, E.; Ilieva, I.; Stanilova, M.; Stoyanov, S.; Sidjimova, B. Reproductive biology of the endangered Bulgarian endemic Centaurea achtarovii (Asteraceae). Biologia 2018, 73, 1163-1175. [CrossRef]

23. Pence, V.C. The possibilities and challenges of in vitro methods for plant conservation. Kew. Bull 2010, 65, 539-547. [CrossRef]

24. Bagheri, F.; Tahvilian, R.; Karimi, N.; Chalabi, M.; Azami, M. Shikonin production by callus culture of Onosma bulbotrichom as active pharmaceutical ingredient. Iran. J. Pharm. Res. 2018, 17, 495-504. 
25. Yaman, C.; Uranbey, S.; Ahmed, H.A.; Özcan, S.; Tugay, O.; Başalma, D. Callus induction and regeneration of Alkanna orientalis var. orientalis and A. sieheana. Bangladesh J. Bot. 2019, 48, 633-640. [CrossRef]

26. Mehrabani, M.; Shams-Ardakani, M.; Ghannadi, A.; Dehkordi, N.G.; Sajjadi-Jazi, S.E. Production of rosmarinic acid in Echium amoenum Fisch. and C.A. Mey. cell cultures. Iran. J. Pharm. Res. 2005, 4, 111-115. [CrossRef]

27. Zare, K.; Khosrowshahli, M.; Nazemiyeh, H.; Movafeghi, A.; Motallebi Azar, A.; Omidi, Y. Callus culture of Echium italicum L. towards production of a shikonin derivative. Nat. Prod. Res. 2011, 25, 1480-1487. [CrossRef] [PubMed]

28. Salehian, H.; Kabirnataj, S.; Bagheri, N.; Nematzadeh, G. Evaluation of capability of in vitro micropropagation in Iranian medicinal plant Echium amoenum Fish and C.A. Mey. Int. J. Biosci. 2014, 4, 58-63. [CrossRef]

29. Turker, A.U.; Yildirim, A.B.; Taş, İ. In vitro adventitious plant regeneration of Echium orientale L., an endemic plant: The evaluation of biological activities and phenolic content. Indian J. Biochem. Biophys. 2018, 55, 264-272.

30. Us-Camas, R.; Rivera-Solís, G.; Duarte-Aké, F.; de-la-Peña, C. In vitro culture: A epigenetic challenge for plants. Plant Cell. Tissue Organ. Cult. 2014, 118, 187-201. [CrossRef]

31. Murashige, T.; Skoog, F. A revised medium for rapid growth and bioassays of tobacco tissue cultures. Physiol. Plant 1962, 15, 473-497. [CrossRef]

32. Galbraith, W. Analysis of higher plants by flow cytometry and cell sorting. Int. Rev. Cytol. 1989, 116, 165-228. [CrossRef]

33. Thiem, B.; Śliwińska, E. Flow cytometric analysis of nuclear DNA content in cloudberry (Rubus chamaemorus L.) in vitro cultures. Plant Sci. 2003, 164, 129-134. [CrossRef]

34. Alexander, M.P. Differential staining of aborted and nonaborted pollen. Stain Technol. 1969, 44, 117-122. [CrossRef]

35. Aloni, R.; Langhans, M.; Aloni, E.; Dreieicher, E.; Ullrich, C.I. Root-synthesized cytokinin in Arabidopsis is distributed in the shoot by the transpiration stream. J. Exp. Bot. 2005, 56, 1535-1544. [CrossRef] [PubMed]

36. Majumder, S.; Rahman, M. In vitro micropropagation of Heliotropium indicum Linn.: An important medicinal Herb. J. Pharmacogn. Phytochem. 2018, 8, 1899-1903.

37. Parray, J.A.; Kamili, A.N.; Jan, S.; Mir, M.Y.; Shameem, N.; Ganai, B.A.; Abd Allah, E.F.; Hashem, A.; Alqarawi, A.A. Manipulation of plant growth regulators on phytochemical constituents and DNA protection potential of the medicinal plant Arnebia benthamii. BioMed. Res. Int. 2018, 2018, 6870139. [CrossRef]

38. Park, H.Y.; Kim, D.H.; Saini, R.K.; Gopal, J.; Keum, Y.S.; Sivanesan, I. Micropropagation and Quantification of Bioactive Compounds in Mertensia maritima (L.) Gray. Int. J. Mol. Sci. 2019, 20, 2141. [CrossRef] [PubMed]

39. Zdravković-Korać, S.; Tubić, L.; Devrnja, N.; Ćalić, D.; Milojević, J.; Milić, M.; Savić, J. Somatic embryogenesis from stamen filaments of Aesculus flava Sol. and peroxidase activity during the transition from friable to embryogenic callus. Sci. Hortic. 2019, 247, 362-372. [CrossRef]

40. Wu, Y.; Ma, Y.D.; Li, Y.; Xia, Y.P. Plantlet regeneration from primary callus cultures of Lilium brownii F.E.Br. ex Miellez var. giganteum Li, G.Y. and Chen, Z.H., a rare bulbous germplasm. In Vitro Cell. Dev. Biol. Plant 2019, 55, 44-59. [CrossRef]

41. Quambusch, M.; Gruß, S.; Pscherer, T.; Winkelmann, T.; Bartsch, M. Improved in vitro rooting of Prunus avium microshoots using a dark treatment and an auxin pulse. Sci. Hortic. 2017, 220, 52-56. [CrossRef]

42. Nameth, B.M.; Goron, T.L.; Dinka, S.J.; Morris, A.D.; English, J.; Lewis, D.; Oro, R.; Raizada, M.N. The initial hours of post-excision light are critical for adventitious root regeneration from Arabidopsis thaliana (L.) Heynh. cotyledon explants. In Vitro Cell. Dev. Biol. Plant 2018, 54, 273. [CrossRef]

43. Dutta Gupta, S.; Jatothu, B. Fundamentals and applications of light-emitting diodes (LEDs) in in vitro plant growth and morphogenesis. Plant Biotechnol. Rep. 2013, 7, 211-220. [CrossRef]

44. Poudyal, B.K.; Du, G.; Zhang, Y.; Liu, J.; Shi, Q. Studies on browning problem and phenols content on shoots of Yali, Aikansui and Abbe Fetel pears for in vitro culture. Front. Agri. China 2008, 2, 321-330. [CrossRef]

45. Aliyu, A.B.; Musa, A.M.; Ibrahim, M.A.; Ibrahim, H.; Oyewale, A.O. Preliminary phytochemical screening and antioxidant activity of leave extract of Albizia chevalieri harms (Leguminoseae-Mimosoideae). Bayero J. Pure App. Sci. 2009, 2, 149-153. [CrossRef]

46. Hamayun, M.; Hussain, A.; Khan, S.A.; Kim, H.Y.; Khan, A.L.; Waqas, M.; Irshad, M.; Iqbal, A.; Rehman, G.; Jan, S.; et al. Gibberellins producing endophytic fungus Porostereum spadiceum agh786 rescues growth of salt affected soybean. Front. Microbiol. 2017, 8, 686. [CrossRef] [PubMed] 
47. Yang, Y.; Liu, Q.; Wang, G.X.; Wang, X.D.; Guo, J.Y. Germination, osmotic adjustment, and antioxidant enzyme activities of gibberellin-pretreated Picea asperata seeds under water stress. New Forests 2010, 39, $231-243$. [CrossRef]

48. Krishna, H.; Alizadeh, M.; Singh, M.; Singh, U.; Chauhan, N.; Eftekhari, M.; Sadh, R.K. Somaclonal variations and their applications in horticultural crops improvement. 3 Biotech. 2016, 6, 54. [CrossRef]

49. Prado, M.J.; Herrera, M.T.; Vázquez, R.A.; Romo, S.; González, M.V. Micropropagation of two selected male kiwifruit and analysis of genetic variation with AFLP markers. HortScience 2005, 40, 740-746. [CrossRef]

50. Farahani, F.; Yari, R.; Masoud, S. Somaclonal variation in Dezful cultivar of olive (Olea europaea subsp. europaea). Gene Conserve 2011, 10, 216-221.

51. Sivanesan, I.; Jeong, B.R. Identification of somaclonal variants in proliferating shoot cultures of Senecio cruentus cv. Tokyo Daruma. Plant Cell Tissue Organ. Cult. 2012, 111, 247-253. [CrossRef]

52. Fay, M.F. In what situation is in vitro culture appropriate to plant conservation? Biodivers. Conserv. 1994, 3, 176-183. [CrossRef]

53. Żabicki, P.; Śliwińska, E.; Mitka, J.; Sutkowska, A.; Tuleja, M.; Migdałek, G.; Żabicka, Ż.; Słomka, A.; Kwiatkowska, M.; Kuta, E.; et al. Does somaclonal variation play advantageous role in conservation practice of endangered species? Comprehensive genetic studies of in vitro propagated plantlets of Viola stagnina Kit. (Violaceae). Plant Cell Tissue Organ. Cult. 2019, 136, 339-352. [CrossRef]

54. Melser, C.; Bijleveld, A.; Klinkhamer, P.G. Late-acting inbreeding depression in both male and female function of Echium vulgare (Boraginaceae). Heredity 1999, 83, 162-170. [CrossRef]

55. Klemow, K.M.; Clements, D.R.; Threadgill, P.F.; Cavers, P.B. The biology of Canadian weeds. 116. Echium vulgare L. Can. J. Plant Sci. 2002, 82, 235-248. [CrossRef]

56. Bischoff, A.; Vonlanthen, B.; Steinger, T.; Müller-Schärer, H. Seed provenance matters-Effects on germination of four plant species used for ecological restoration. Basic Appl. Ecol. 2006, 7, 347-359. [CrossRef]

57. Bischoff, A.; Müller-Schärer, H. Testing population differentiation in plant species-how important are environmental maternal effects. Oikos 2010, 119, 445-454. [CrossRef]

58. Sharaf, A.R.N.; Hamidoghli, Y.; Zakizadeh, H. In vitro seed germination and micropropagation of primrose (Primula heterochroma Stapf.) an endemic endangered Iranian species via shoot tip explants. Hortic. Environ. Biotechnol. 2011, 52, 298-302. [CrossRef]

59. Gutterman, Y. Maternal effects on seeds during development. In Seeds: The Ecology of Regeneration in Plant Communities, 2nd ed.; Fenner, M., Ed.; Oxford University Press: Oxford, UK, 2000; pp. 59-84.

60. Helenurm, K.; Schaal, B.A. Genetic and maternal effects on offspring fitness in Lupinus texensis (Fabaceae). Am. J. Bot. 1996, 83, 1596-1608. [CrossRef]

61. Wulff, R.D.; Causin, H.F.; Benitez, O.; Bacalini, P.A. Intraspecific variability and maternal effects in the response to nutrient addition in Chenopodium album. Can. J. Bot. 1999, 77, 1150-1158. [CrossRef]

62. Kuzemko, A.A. (Ed.) Finds of Plants and Fungi of the Red Book and the Berne Convention (Resolution 6); Issue Kyiv-Chernivtsi: Kiev, Ukraine, 2019; pp. 1-496.

63. Linhart, Y.B.; Grant, M.C. Evolutionary significance of local genetic differentiation in plants. Annu. Rev. Ecol. Syst. 1996, 27, 237-277. [CrossRef]

64. Jacquemyn, H.; de Meester, L.; Jongejans, E.; Honnay, O. Evolutionary changes in plant reproductive traits following habitat fragmentation and their consequences for population fitness. J. Ecol. 2012, 100, $76-87$. [CrossRef]

65. Kar, P.; Chakraborty, A.K.; Bhattacharya, M.; Mishra, T.; Sen, A. Micropropagation, genetic fidelity assessment and phytochemical studies of Clerodendrum thomsoniae Balf. f. with special reference to its anti-stress properties. Res. Plant Biol. 2019, 9, 9-15. [CrossRef]

66. Jędrzejczyk, I.; Morozowska, M.; Nowińska, R.; Jagodziński, A.M. Primula veris plants derived from in vitro cultures and from seeds: Genetic stability, morphology, and seed characteristics. Turk. J. Bot. 2018, 42, 412-422. [CrossRef]

67. Duarte-Aké, F.; Castillo-Castro, E.; Pool, F.B.; Espadas, F.; Santamaría, J.M.; Manuel, L.; Robert, M.L.; de-la-Peña, C. Physiological differences and changes in global DNA methylation levels in Agave angustifolia Haw. albino variant somaclones during the micropropagation process. Plant Cell Rep. 2016, 35, 2489-2502. [CrossRef] [PubMed]

68. Trejgell, A.; Dabrowska, A.; Tretyn, A. Micropropagation and influence of in vitro culture on development of Cirsium pannonicum (L. f.) LINK regenerants. Acta Sci. Pol. Hortorum Cultus 2012, 11, 81-90. 
69. Falk, D.A.; Holsinger, K.E. Genetics and Conservation of Rare Plants; Oxford University Press: New York, NY, USA, 1991; pp. 1-283.

70. Vergeer, P.; Sonderen, E.; Ouborg, J.N. Introduction strategies put to the test: Local adaptation versus heterosis. Conserv. Biol. 2004, 18, 812-821. [CrossRef]

71. Kramer, A.; Havens, K. Plant conservation genetics in a changing world. Trends Plant Sci. 2009, 14, 599-607. [CrossRef] [PubMed]

72. Keller, M.; Kollman, J.; Edwards, P.J. Genetic introgression from distant provenances reduces fitness in local weed populations. J. Appl. Ecol. 2000, 37, 647-659. [CrossRef]

73. Montalvo, A.; Ellstrand, N. Nonlocal transplantation and outbreeding depression in the subshrub Lotus scoparius (Fabaceae). Am. J. Bot. 2001, 88, 258-269. [CrossRef]

74. Maschinski, J.; Wright, S.J.; Koptur, S.; Pinto-Torres, E.C. When is local the best paradigm? Breeding history influences conservation reintroduction survival and population trajectories in times of extreme climate events. Biol. Conserv. 2013, 159, 277-284. [CrossRef]

(C) 2020 by the authors. Licensee MDPI, Basel, Switzerland. This article is an open access article distributed under the terms and conditions of the Creative Commons Attribution (CC BY) license (http://creativecommons.org/licenses/by/4.0/). 